\title{
A simplified subtractive hybridization protocol used to isolate DNA sequences specific to Xylella fastidiosa
}

\author{
Henrique Ferreira, ${ }^{1}$ Julio Rodrigues Neto, ${ }^{2}$ Edmilson R. Gonçalves ${ }^{1}$ \\ and Yoko B. Rosato' \\ Author for correspondence: Yoko B. Rosato. Tel: +55 19 7881135. Fax: +55 197881089. \\ e-mail: yrosato@obelix.unicamp.br
}

\footnotetext{
1 Department of Genetics and Evolution, IB and CBMEG, State University of Campinas, CP 6109, 13083970, Campinas, SP, Brazil

2 Instituto Biológico, Section of Phytopathological Bacteriology, 13001-970, Campinas, SP, Brazil
}

\begin{abstract}
A simplified protocol of subtractive hybridization based on the technique of $L$. M. Kunkel, A. P. Monaco, W. Middlesworth, H. D. Ochs \& S. A. Latt (1985, Proc Natl Acad Sci USA, 82, 4778-4782) was used to obtain DNA sequences specific to Xylella fastidiosa isolated from diseased citrus plants. As a driver, DNA extracted from bacteria showing different degrees of relatedness was used: $X y$. fastidiosa 788 isolated from another host (plum), Xanthomonas campestris pv. campestris and Burkholderia gladioli strains. A DNA fragment, f14, showing no hybridization to the driver DNA, was used as a probe specific to $X y$. fastidiosa from citrus and oleander. This fragment was sequenced and the predicted protein showed $40 \%$ similarity to the central region of flagellin of Escherichia coli serotypes $\mathrm{H1}$ and $\mathrm{H12}$. A pair of internal primers (f14-1 and f142) was designed for amplification of $X y$. fastidiosa DNA. These primers detected $X y$. fastidiosa strains isolated from citrus and oleander and yielded an amplification product of about $600 \mathrm{bp}$. They were also able to detect the bacteria in extracts from citrus plants with or without symptoms of disease. No amplification reaction was obtained using DNA extracted from other species and pathovars of Xanthomonas, Pseudomonas cichorii, Erwinia carotovora, Agrobacterium tumefaciens and phytopathogens of citrus (Xanthomonas axonopodis pv. citri) and coffee (Burkholderia andropogonis, P. cichorii, Pseudomonas syringae pv. garcae). The isolation of a DNA fragment specific to $X y$. fastidiosa from citrus showed that the simplified protocol of subtractive hybridization used in this work is potentially applicable to other microorganisms.
\end{abstract}

Keywords: Xylella fastidiosa, subtractive hybridization, PCR detection

\section{INTRODUCTION}

One problem commonly found during the analysis and comparison of similar genomes is the isolation of differential DNA sequences. This situation arises in the design of specific probes and the analysis of related organisms or those differing by a mutant phenotype. Using phenol-accelerated competitive DNA hybridization, Kunkel et al. (1985) isolated specific fragments from the DNA of a male patient with an X

Abbreviation: CVC, citrus variegated chlorosis.

The GenBank accession number for the sequence reported in this paper is AF052587. chromosome deletion. The method has been modified gradually by different authors, introducing more steps of competitive hybridization which permitted higher levels of enrichment of specific sequences (see, for example, Straus \& Ausubel, 1990). In addition, adaptors ligated to the subtracted sequences were used for amplification by PCR. The method of subtractive hybridization has been widely used and has been employed in the phytopathology area mainly to isolate specific probes for the detection of certain pathogens, as described for Pseudomonas (Cook \& Sequeira, 1991), Erwinia (Darrasse et al., 1994), Clavibacter (Mills et al., 1997) and Xanthomonas (Kuflu \& Cuppels, 1997).

In our work, a simplified procedure of subtractive 
hybridization based on the method described by Kunkel et al. (1985) was used to isolate DNA sequences specific to Xylella fastidiosa isolated from diseased citrus plants. $X y$. fastidiosa is a unique species in the genus and consists of several pathotypes causing diseases in economically important plants, including alfalfa, almond, grapevine, peach and plum (for a review see Hopkins, 1989; Purcell \& Hopkins, 1996). New diseases associated with $X y$. fastidiosa have recently been described in orange (Chang et al., 1993; Hartung et al., 1994) and coffee (Beretta et al., 1996; Paradela-Filho et al., 1997; Lima et al., 1998) trees in Brazil; these diseases were designated citrus variegated chlorosis (CVC) and coffee leaf scald, respectively. A rapid dissemination of CVC is occurring in the major citrus-growing areas in Brazil, with associated large economic losses. The extent of the damage in coffee plants is still undetermined.

Highly sensitive and reliable methods for detecting the bacterium are important in strategies to control the spread of the disease. Currently, the detection of CVC$X y$. fastidiosa is performed by visual inspection of plants, microscopy and serological techniques such as ELISA and the dot immunobinding assay (Garnier $e t$ al., 1993; Lee et al., 1992). The employment of these techniques is sometimes ambiguous and culturing the bacteria is a tedious and slow process. Due to the outbreak of CVC in Brazil, PCR-based techniques have been developed for Xy. fastidiosa (Minsavage et al., 1994; Pooler \& Hartung, 1995). More sensitive techniques permitting the detection of the bacterium before the development of symptoms are important to control the spread of CVC. Bacterial infection can occur during the grafting procedure from contaminated rootstocks, in the unprotected nursery, or in the field by sharpshooter leafhopper insects, which are the natural vectors (for a review see Carlos et al., 1997).

In this paper we describe a procedure of subtractive hybridization used to isolate DNA sequences specific to $X y$. fastidiosa. Using this approach, a DNA probe hybridizing to CVC- and oleander- $X y$. fastidiosa was identified. This fragment was sequenced and a pair of primers designed for the PCR detection of the bacterium isolated from citrus and oleander, and in extracts prepared from symptomatic or symptomless/inoculated citrus plants.

\section{METHODS}

Bacterial strains, growth conditions and plasmids. The strains used in this work are listed in Table 1. Agrobacterium, Enterobacter, Erwinia and Escherichia coli DH5 $\alpha$ strains were grown in LB medium (Sambrook et al., 1989); Pseudomonas, Burkholderia and Xanthomonas strains were grown in NYGagar medium (Turner et al., 1984); and Xylella strains were grown in SPW-agar medium (Hartung et al., 1994). The incubation temperature was $30^{\circ} \mathrm{C}$ for all strains, except for $E$. coli $\left(37^{\circ} \mathrm{C}\right)$. The plasmid pBluescript $\mathrm{KS}+$ (Stratagene) was used as a cloning vector.

DNA extraction. Ten milligrams of $X y$. fastidiosa bacterial mass was collected from SPW-agar plates and placed into
$1.5 \mathrm{ml}$ microfuge tubes. The cellular mass was washed once in $500 \mu \mathrm{l}$ TAS buffer $(50 \mathrm{mM}$ Tris $/ \mathrm{HCl} \mathrm{pH} 8 \cdot 0,50 \mathrm{mM}$ EDTA, $150 \mathrm{mM} \mathrm{NaCl}$ ), centrifuged and the pellet was resuspended in $500 \mu$ lysis buffer (TAS plus $1 \%$ SDS and $150 \mu$ g proteinase $\mathrm{K}$ $\left.\mathrm{ml}^{-1}\right)$. The tubes were incubated at $50^{\circ} \mathrm{C}$ for $1 \mathrm{~h}$. The cell debris was extracted once with phenol and twice with chloroform and dialysed for $48 \mathrm{~h}$ against TE buffer $(10 \mathrm{mM}$ Tris/ $\mathrm{HCl} \mathrm{pH} 8.0,1 \mathrm{mM}$ EDTA). DNA concentration was determined by comparison with lambda DNA in ethidiumbromide-stained $0.8 \%$ agarose gel. Plasmid extraction was carried out using the alkaline lysis method (Sambrook et al., 1989).

DNA manipulation and hybridization. Restriction enzyme digestion and ligation of DNA molecules were carried out following the manufacturers' specifications. General DNA manipulation procedures were carried out according to Sambrook et al. (1989). Small DNA fragments were visualized in $7 \%$ polyacrylamide/bis-acrylamide gels $(49: 1, \mathrm{w} / \mathrm{w})$ in a Tris/borate/EDTA buffer system, using a silver staining method (Moreno et al., 1985). In the slot-blot hybridization experiments, $1 \mu \mathrm{g}$ genomic DNA was placed onto nylon membranes using a hybri-slot filtration manifold. The DNA was denatured for $5 \mathrm{~min}(1.5 \mathrm{M} \mathrm{NaCl}, 0.5 \mathrm{NaOH})$, neutralized for $5 \mathrm{~min}(1.5 \mathrm{M} \mathrm{NaCl}, 0.5 \mathrm{M}$ Tris $/ \mathrm{HCl} \mathrm{pH} \mathrm{7.2,} 1 \mathrm{mM}$ EDTA), dried and baked for $2 \mathrm{~h}$ at $80^{\circ} \mathrm{C}$ prior to the hybridization procedures. For Southern blot hybridization, $2 \mu \mathrm{g}$ digested genomic DNA was separated in a $0.8 \%$ agarose gel and blotted onto nylon membranes using the alkaline transfer method. Plasmid vectors harbouring DNA fragments (cloned into BamHI sites) to be labelled were extracted, digested with Pst I and $\mathrm{XbaI}$ and separated in a $0.8 \%$ lowmelting-point agarose gel. Purified fragments were labelled using the DIG DNA labelling kit and detection of bands was carried out using the chemiluminescent substrate CSPD [disodium 3-(4-methoxyspiro\{1,2-dioxetane-3,2'-(5'-chloro)tricyclo[3.3.1.1 $1^{3.7}$ decan $\left.\}-4-y l\right)$ phenyl phosphate] as recommended by the manufacturer (Boehringer Mannheim).

Plant DNA preparation. DNA from plant extracts was obtained by grinding approximately $300 \mathrm{mg}$ citrus or coffee petioles under liquid nitrogen in a chilled mortar and pestle. The following steps were the same as described by Doyle $\&$ Doyle (1990). After precipitation, the DNA pellet was suspended in $40 \mu \mathrm{l} \mathrm{TE}$ buffer and $4 \mu \mathrm{l}$ was used in the PCR reactions. The extracts were prepared from healthy and CVCaffected Citrus sinensis adult plants growing in the field, as well as from healthy seedlings. Symptomless citrus seedlings artificially inoculated with $X y$. fastidiosa were also used. These seedlings were inoculated 6 months in advance, using different procedures ( $\mathrm{J}$. Rodrigues Neto, unpublished data). Leaves from symptomatic and healthy adult coffee (Coffea arabica) plants or seedlings of cv. Mundo Novo and cv. Catuaí were provided by the Instituto Biológico, Campinas, SP, Brazil by O. Guerreiro Filho (IAC, Campinas, SP, Brazil).

Subtractive hybridization and cloning. Tester genomic DNA of $X y$. fastidiosa isolated from citrus showing CVC symptoms was totally digested with Sau3AI and fragments between 0.5 and $2.0 \mathrm{~kb}$ were purified from a $0.8 \%$ low-melting-point agarose gel. Approximately $1 \mathrm{mg}$ driver DNA was sheared by sonication using an Ultrasonic Homogenizer (Cole-Parmer), until fragments with an average size of $500 \mathrm{bp}$ were obtained as the major component. As a driver, DNA from Xy. fastidiosa 788, Xanthomonas campestris pv. campestris and Burkholderia gladioli, was used. Ten micrograms of driver DNAs were mixed with 100 ng tester DNA $(100: 1, w / w)$ and denatured in a water bath at $100^{\circ} \mathrm{C}$ for $10 \mathrm{~min}$. The mixture 
Table 1. Bacterial strains used

\begin{tabular}{|c|c|c|}
\hline Strain & Hosts & Origin and other references* \\
\hline Agrobacterium tumefaciens & Wide range of plants & IBSBF $304=$ ICMP 5793; ATCC 4720 \\
\hline Burkbolderia andropogonis & Coffea arabica cv. Catuí amarelo & IBSBF $166=$ ICMP $6779 ;$ NCPPB 6943 \\
\hline Burkholderia gladioli pv. gladioli & Gladiolus sp. & IBSBF $604=$ ICMP 9382 \\
\hline Enterobacter dissolvens & Zea mays & IBSBF $1289=$ ICMP 1570 \\
\hline Erwinia carotovora subsp. carotovora & Solanum tuberosum & $\begin{array}{l}\text { IBSBF } 863=\text { ICMP 5702; ATCC } 15713 ; \\
\text { LMG } 2404\end{array}$ \\
\hline \multicolumn{3}{|l|}{ Pseudomonas } \\
\hline P. cichorii & Coffea arabica & IBSBF $587=$ ICMP 9276; NCPPB 3109 \\
\hline P. syringae pv. garcae & Coffea arabica & IBSBF 1297 \\
\hline$P$. syringae pv. syringae & Syringa vulgaris & $\begin{array}{l}\text { IBSBF } 451=\text { ICMP } 3023 ; \text { LMG } 1247 \\
\text { ATCC } 19310\end{array}$ \\
\hline \multicolumn{3}{|l|}{ Xanthomonas } \\
\hline Xa. axonopodis pv. citri & Citrus sinensis & IBSBF 223 \\
\hline Xa. axonopodis pv. phaseoli & Phaseolus vulgaris & LMG 7455 \\
\hline $\mathrm{Xa}$. campestris pv. campestris & Crucifers & Ca110 (Destefano \& Rosato, 1991) \\
\hline Xa. translucens pv. translucens & Hordeum vulgare & LMG 876 \\
\hline Xa. translucens pv. undulosa & Triticum aestivum & IBSBF 1026 \\
\hline \multicolumn{3}{|l|}{ Xylella fastidiosa } \\
\hline $\mathrm{A} 1, \mathrm{~A} 4, \mathrm{E} 4, \mathrm{E} 6, \mathrm{~F} 5, \mathrm{H} 9, \mathrm{~B} 1, \mathrm{~B} 7, \mathrm{~B} 9, \mathrm{JB} 1, \mathrm{C} 6, \mathrm{C} 10$ & Citrus sinensis & Fundecitrus \\
\hline CF01, CF02, CF03, 11752,12288 & From Coffea arabica & Fundecitrus; IAPAR \\
\hline GP01 & From Vitis vinifera & IBSBF $789=$ ATCC 33107 \\
\hline OL01 & From Nerium oleander & Fundecitrus \\
\hline PL9746 & From Prunus salicina & IAPAR 9746 \\
\hline PL788 & From Prunus salicina & IBSBF $788=$ ICMP 8735 \\
\hline
\end{tabular}

*ATCC, American Type Culture Collection, Manassas, VA, USA; Fundecitrus, Fundo Paulista de Defesa da Citricultura, Araraquara, SP, Brazil; IAPAR, Instituto Agronômico do Paraná, Londrina, PR, Brazil; IBSBF, Instituto Biológico, Seção de Bacteriologia Fitopatológica, Campinas, SP, Brazil; ICMP, International Collection of Microorganisms from Plants, Auckland, New Zealand; LMG, Culture Collection of the Laboratorium voor Microbiologie, Rijksuniversiteit, Gent, Belgium; NCPPB, National Collection of Plantpathogenic bacteria, CSL, York, England.

was transferred to a $50 \mathrm{ml}$ centrifuge tube, $50 \mu \mathrm{l}$ phenol was added and the final volume adjusted to $500 \mu \mathrm{l}$ with TE buffer. The phenol aqueous emulsion permits increase in the rate of DNA-DNA reassociation many thousand times faster than under standard conditions (Kohne et al., 1977). The optimum rate is obtained by vigorous shaking of the emulsion. In the present case, a vortex mixer at medium speed was used for 48 $\mathrm{h}$. The whole mixture was cleaned using phenol and chloroform and the products were ligated to BamHI-digested pBluescript KS + cloning vector and electrotransformed into E. coli DH5 $\alpha$ strain. White colonies were selected by plating the cells after transformation onto LB-agar medium supplemented with ampicillin $\left(60 \mu \mathrm{g} \mathrm{ml}^{-1}\right)$ and X-Gal $\left(40 \mu \mathrm{g} \mathrm{ml}^{-1}\right)$.

DNA sequencing and analysis. Fragments cloned into the pBluescript $\mathrm{KS}+$ vector were sequenced using the Thermo Sequenase dye terminator cycle sequencing pre-mix kit (Amersham) and the primers M13 and Reverse (Gibco-BRL). The samples were read in an automatic sequencer ABI Prism 377 (Perkin Elmer). For DNA sequence and primer analysis the Gene Runner, version 3.0 (Hastings Software), DNASIS version 6.0 (Hitachi Software Engineering) and Oligo structure, version 3.3 (National BioScience) were used.

PCR conditions for amplification using the designed primers (f14). Bacterial DNA or cells were amplified using the Thermal
Cycler (Perkin Elmer) in the following conditions: 10-20 ng genomic DNA, 1.0-1.5 $\mathrm{mM} \mathrm{MgCl}_{2}, 100 \mu \mathrm{M}$ dNTPs, $1-5 \mathrm{pmol}$ of each primer, 0.5 units Taq DNA polymerase and buffer as recommended (Gibco-BRL) and water to $25 \mu \mathrm{l}$. The PCR cycling condition was: $1 \times\left(94^{\circ} \mathrm{C} / 2 \mathrm{~min}\right) ; 40 \times\left(94^{\circ} \mathrm{C} / 30 \mathrm{~s}\right.$, $62-64^{\circ} \mathrm{C} / 30 \mathrm{~s}$ and $\left.72{ }^{\circ} \mathrm{C} / 45 \mathrm{~s}\right)$.

\section{RESULTS}

\section{Cloning CVC-Xy. fastidiosa-specific DNA by subtractive hybridization}

This technique was used to selectively clone DNA sequences of CVC-Xy. fastidiosa which are absent from $X y$. fastidiosa from another host (plum) and related bacteria. The method used is shown in Fig. 1. The driver DNAs, from different bacterial species, were chosen based on the different levels of relatedness to $X y$. fastidiosa. One was a strain of $X y$. fastidiosa isolated from another host (plum); Xa. campestris is a phytopathogenic bacterium close related to $X y$. fastidiosa; and B. gladioli, formerly Pseudomonas gladioli, is a more distantly related pathogen. The rationale of using DNA from different pathogens is to exhaust the house- 
Tester DNA

CVC-Xy. fastidiosa A1

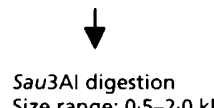

Size range: $0.5-2.0 \mathrm{~kb}$

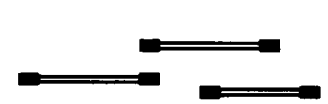

Driver DNA

Plum-Xy. fastidiosa 788

$X$ a. campestris pv. campestris Ca110

B. gladioli pv. gladioli 604

Sonicated DNA

Size range: $0.3-1.0 \mathrm{~kb}$

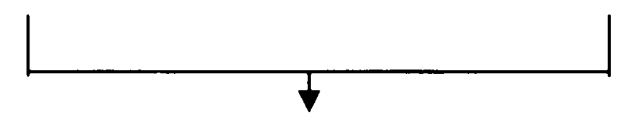

Mix the DNAs (1:100, tester to driver)

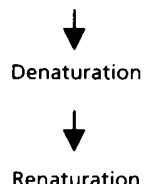

Renaturation

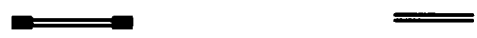

Fragments showing Sau $3 \mathrm{Al}$ ends in both strands

No Sau3Al ends

Fragments showing Sau3Al ends in one strand

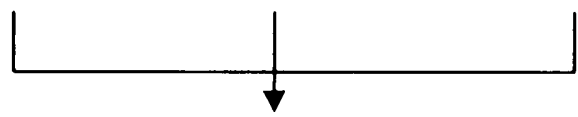

Cloning the whole mixture into BamHI/pKS + vector

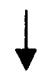

Enriched library for CVC-Xy. fastidiosa sequences

Fig. 1. Diagram of the simplified subtractive hybridization used to isolate DNA sequences specific to CVC-Xy. fastidiosa.

keeping and pathogenicity-related genes that they might have in common. In the first screening, 47 white colonies were isolated and subjected to plasmid extraction and restriction analysis using $H$ indIII and $S s t \mathrm{I}$, which cut at the flanking edges of the cloned fragment. Most of the clones possessed inserts of 200-300 bp, which were discarded. Four recombinant plasmids had inserts sizes between 600 and $700 \mathrm{bp}$ and these inserts ( $\mathrm{f} 9, \mathrm{f} 14, \mathrm{f} 40$ and $\mathrm{f45}$ ), showing differences in the restriction sites for $B g l$ and HaeII, were tested as probes specific for CVCXy. fastidiosa.

\section{Specificity of the selected clones from the subtractive library}

To assess the specificity of each of the four fragments obtained and the homology among these potential probes, slot-blot hybridization experiments were carried out. Four membranes were prepared using DNA from $X y$. fastidiosa strains isolated from citrus (A1, C6 and E4), from the strains used as drivers in the subtractive hybridization (Xy. fastidiosa PL788, Xa. campestris pv. campestris and B. gladioli pv. gladioli) and the isolated fragments $\mathrm{f} 9, \mathrm{f14}, \mathrm{f} 40$ and $\mathrm{f} 45$. Each membrane was hybridized individually using one of the four labelled fragments ( $\mathrm{f} 9, \mathrm{f} 14, \mathrm{f} 40$ and $\mathrm{f} 45)$ as probes. No homology was detected among the four fragments. All probes showed no hybridization to the DNA from $\mathrm{Xa}$. campestris and B. gladioli used as driver DNA. However, three of them ( $\mathrm{f} 9, \mathrm{f} 40$ and $\mathrm{f} 45$ ) hybridized to DNA from $X y$. fastidiosa PL788. The fragment $\mathrm{f} 14$ showed no hybridization to any driver DNA and therefore it was chosen for further analysis. Slot-blot experiments were carried out to confirm its specificity to CVC-Xy. fastidiosa. DNA of five strains of $X y$. fastidiosa from different hosts (citrus A1, coffee CF01, oleander OL01, plum PL788 and grapevine GP01) and strains of different species and genera (Xanthomonas axonopodis pv. citri, $X a$. axonopodis pv. phaseoli, Xa. campestris $p v$. campestris, Xanthomonas translucens pv. translucens, $\mathrm{Xa}$. translucens pv. undulosa, Pseudomonas cichorii, Pseudomonas syringae pv. garcae, P. syringae pv. 
(a)

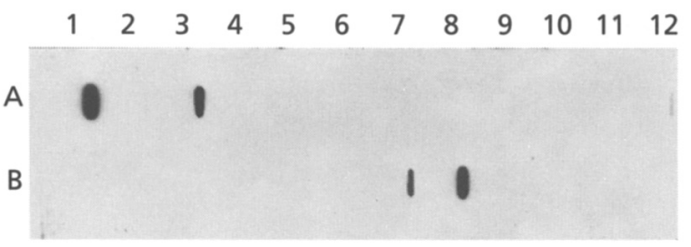

(b)

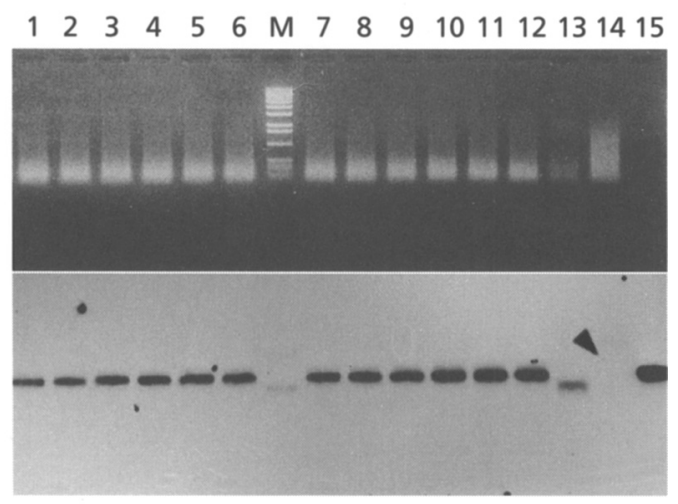

(c)

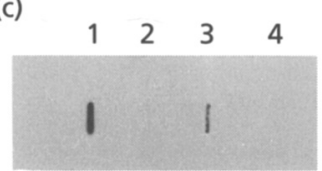

Fig. 2. Hybridization experiments using $f 14$ as a probe. (a) Slotblot using DNA from different isolates of $X y$. fastidiosa and control strains of different genera: $A 1$, citrus $A 1 ; A 2$, coffee CF01; $A 3$, oleander OL01; A4, plum PL788; A5, grapevine GP01; A6, Xa. axonopodis pv. citri; A7, Xa. axonopodis pv. phaseoli; $A 8, X a$. campestris pv. campestris; A9, Xa. translucens pv. translucens; A10, Xa. translucens pv. undulosa; A11, P. cichorii; $A 12, P$. syringae pv. garcae; B1, $P$. syringae pv. syringae; B2, A. tumefaciens; B3, B. gladioli pv. gladioli; B4, B. andropogonis; B5, En. dissolvens; B6, Er. carotovora subsp. carotovora; B7, E. coli $\mathrm{DH} 5 \alpha$; B8, fragment $f 14$. (b) Southern blot of Sau3Aldigested DNA. Lanes: 1-12, CVC-Xy. fastidiosa A1, A4, E4, E6, F5, H9, B1, B7, B9, JB1, C6, C10, respectively; 13-15, OL01, DH5x and $f 14$ fragment, respectively; $M$, DNA molecular mass markers (1.0 kb ladder, Gibco-BRL). (c) Slot-blot using citrus plant extracts. Lanes: 1, symptomatic adult plant; 2, healthy adult plant; 3, symptomless/inoculated seedling; 4, healthy seedling.

syringae, Agrobacterium tumefaciens, B. gladioli pv. gladioli, Burkholderia andropogonis, Enterobacter dissolvens, Erwinia carotovora subsp. carotovora and E. coli DH5 $\alpha$ were tested with probe $\mathrm{f} 14$. There was hybridization with DNA from strains A1 (from CVC), OL01 (from oleander) and E. coli DH5 $\alpha$ (Fig. 2a). No hybridization was detected with $X y$. fastidiosa DNA from coffee (CF01), plum (PL788), grape (GP01), or with DNA from the other bacteria tested. Confirmation of the slot-blot experiments was carried out by Southern blot hybridization using 12 other strains of $X y$. fastidiosa from CVC. The DNA was digested with Sau3AI and the results showed the expected hybridization band of about
$670 \mathrm{bp}$ (Fig. 2b). Strains OL01 and DH5 2 , which hybridized with $\mathrm{f} 14$ in the previous slot-blot hybridization tests, were included in these Southern experiments. OL01 strain showed a hybridization band of $0.5 \mathrm{bp}$ whereas $E$. coli DH5 $\alpha$ showed a higher molecular mass and less intense band of about $1.6 \mathrm{~kb}$ (arrowhead in Fig. 2b).

The ability of $\mathrm{f} 14$ to detect $X y$. fastidiosa was also tested in plant extracts. Samples of $4 \mu \mathrm{l}$ plant extracts were slot-blotted and used in hybridization tests. Probe f14 detected the bacteria in extracts prepared from symptomatic and symptomless/inoculated citrus plants (Fig. 2c).

\section{Primer design and their use in PCR tests}

The entire fragment $\mathrm{f} 14$ was sequenced and a total of $669 \mathrm{bp}$ was found. Homology in the nucleotide sequence was found with a small stretch (21 nucleotides) of an unidentified region of the Bacillus subtilis genome and to several stretches of the $E$. coli flagellin gene $(f l i C)$. A search for homology in the deduced a mino acid sequence of $\mathrm{f} 14$ revealed similarity to the FliC protein (flagellin) from morphotype $\mathrm{E}$ flagellar filaments of $E$. coli serotypes H1 and H12 (Schoenhals \& Whitfield, 1993). The amino acid sequences of $\mathrm{H} 1$ and $\mathrm{H} 12$ flagellin are very similar, differing only by 10 amino acid residues. The central region of the flagellin molecule of $E$. coli is variable, giving rise to serotype-specific epitopes and the terminal regions are highly conserved in $E$. coli and other bacterial species (Harshey et al., 1989; Smith \& Selander, 1990; Wei \& Joys, 1986). The identity of F14 to $\mathrm{H} 1$ was $28 \%(59 / 209)$ and similarity was $40 \%$ $(85 / 209)$. The intriguing result was that this similarity was detected within the variable region of the flagellin of E. coli. The alignment of F14 and FliC sequences (Fig. $3 a)$ showed several gaps and the similarity in the amino acid sequence seems to occur randomly. There are no major domains and in the best cases there is a sequence of five identical contiguous amino acids.

Based on the flanking sequences, a pair of oligonucleotides was designed for PCR experiments. The selected sequences were: F14-1, 5'-ACC GTT GGC GTC CGT ATA GG-3'; and F14-2, 5'-GAC ATG GCT GCT CAC CTG G-3' (Fig. 3b). An amplification product of about $600 \mathrm{bp}$ was expected by using these primers. These primers were tested with five strains of $X y$. fastidiosa isolated from different hosts (A1, OL01, CF01, PL788 and GP01). Only strains A1, from citrus, and OL01, from oleander, showed the diagnostic band of $600 \mathrm{bp}$ (Fig. 4a). The amplification products were blotted and hybridized with the probe f14 and strong bands were observed with A1 and OL01 strains (Fig. 4a). A further distinction between the PCR products of $X y$. fastidiosa from citrus and oleander, made by a subsequent digestion with Sau3AI, showed that there was an internal site for this enzyme only in the fragment from the OL01 strain. All CVC-Xy. fastidiosa strains presented in Table 1 were subsequently tested with these 
(a)

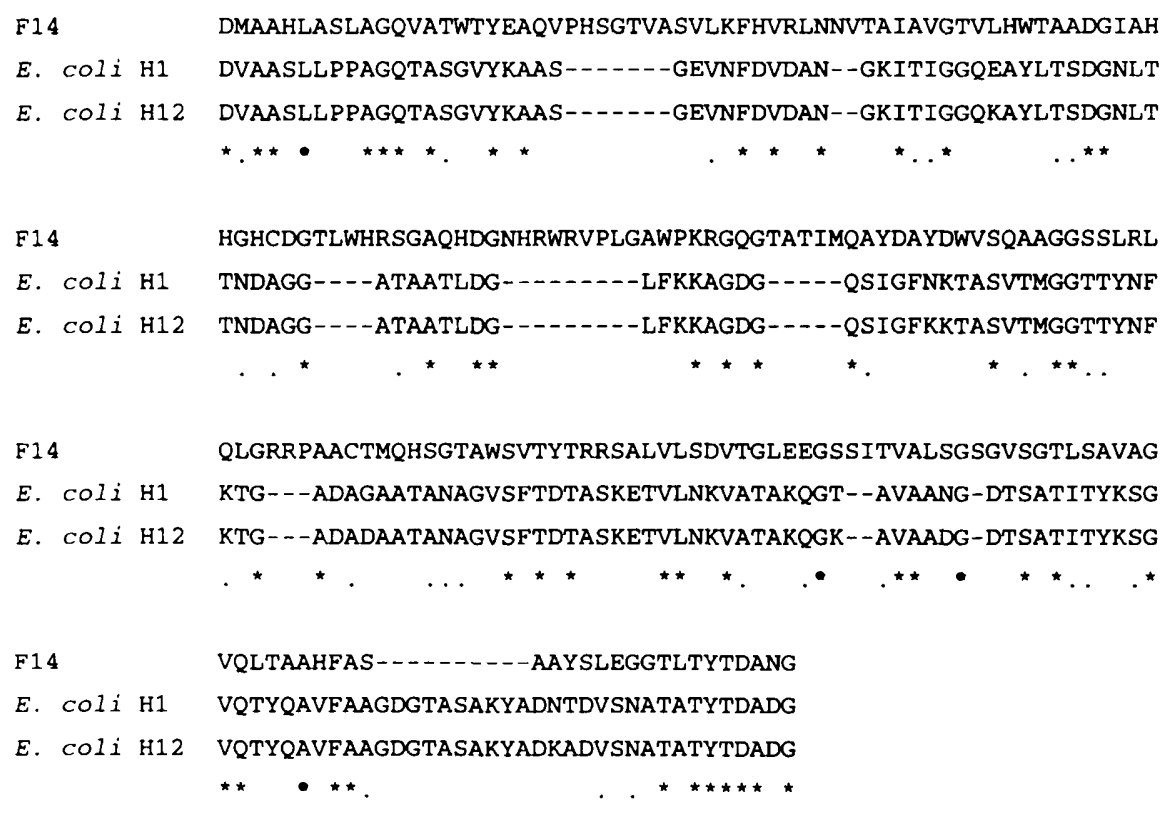

(b)

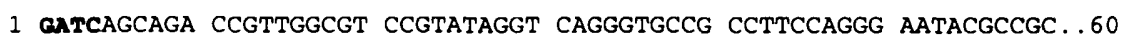

стגGTCGTCT GGCAACCGCA GGCATATCCA GTCCCACGGC GGAAGGTCCC TTATGCGGCG...

f14-1

610. TCGCTGCGGT CCACTCGTCG GTACAGTCCC TGGTCCTGCA CACGCGGGAC GCCGCOTAG 669

... AGCGACGCCA GGTGAGCAGC CATGTCAGGG ACCAGGACGT GTGCGCCCTG CGGCGAATC

f14-2

Fig. 3. (a) Alignment of the predicted amino acid sequence of the f14 DNA sequence to the flagellin gene (fliC) of $E$. coli serotypes $\mathrm{H} 1$ and $\mathrm{H} 12$. (b) Partial nucleotide sequence of $\mathrm{f} 14$ showing the annealing positions of primers $\mathrm{f14}-1$ and $\mathrm{f} 14-2$ (underlined) and the Sau3Al sites (in bold).

primers and the same $600 \mathrm{bp}$ product was observed for all strains. An unexpected result was obtained with $X y$. fastidiosa isolated from coffee. Three strains (CF01, CF02 and 11752) isolated in the São Paulo State gave no amplification products; however, two strains (12288 and 11782) from another state (Paraná) amplified the $600 \mathrm{bp}$ fragment. The specificity of these primers was also tested using DNA from different bacterial species (E. coli DH5 , Xa. axonopodis pv. citri, Xa. axonopodis pv. phaseoli, Xa. campestris pv. campestris, Xa. translucens pv. translucens, Xa. translucens pv. undulosa, $P$. cichorii, P. syringae pv. garcae, P. syringae pv. syringae, A. tumefaciens, B. gladioli pv. gladioli, B. andropogonis, En. dissolvens and Er. carotovora subsp. carotovora) and no amplification products were detected (Fig. 5).

For detection of $X y$. fastidiosa in citrus plant extracts, $4 \mu \mathrm{l}$ of each extract was used in the amplification reaction. The primers successfully detected the presence of the bacterium in extracts prepared from symptomatic or symptomless/inoculated citrus plants (Fig. 4b). There was no amplification when extracts from healthy citrus plants were used.

\section{Sensitivity of detection of the primers $f 14$}

To determine the detection level of $\mathrm{f} 14$ primers by PCR, tenfold serial dilutions were prepared from an initial cell suspension of $X y$. fastidiosa A1 $\left(\mathrm{OD}_{600} 0 \cdot 33\right)$ and $4 \mu \mathrm{l}$ of each suspension was used in the PCR reactions. Bacteria were detected up to a $10^{4}$-fold dilution. Detection was based on the presence of the diagnostic band in agarose gel, for which the total volume of the amplification reaction was loaded. Given that an $\mathrm{OD}_{600}$ of 0.25 corresponds to $10^{7}-10^{8}$ cells $\mathrm{ml}^{-1}$ (Minsavage et al., 1994), the PCR reaction using $\mathrm{f} 14$ primers was able to detect 5-50 cells, which is quite similar to the sensitivity described by Minsavage et al. (1994). 
(a)

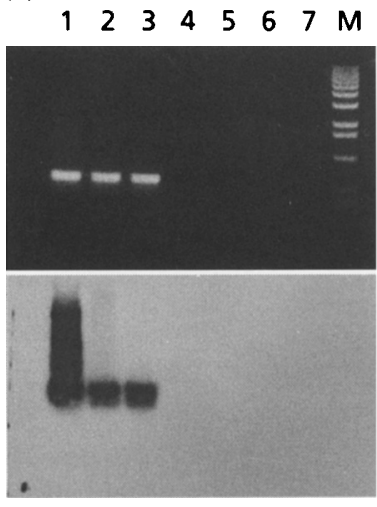

(b)

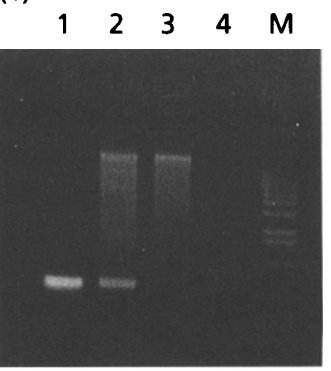

Fig. 4. (a) Agarose gel electrophoresis of PCR products from $x y$. fastidiosa strains using primers $\mathrm{f14}$ and the Southern blot hybridization with the probe f14. Lanes: $M$, DNA molecular mass markers (1.0 kb ladder, Gibco-BRL); $1-7$, f14 fragment cloned into pBluescript KS + vector, A1, OL01, CF01, PL788, GP01 and control reaction lacking DNA template, respectively. (b) Agarose gel electrophoresis of PCR products from citrus plant extracts using primers f14. Lanes 1-4, symptomatic adult plant, symptomless/inoculated seedling, healthy adult plant and control reaction lacking DNA template, respectively.

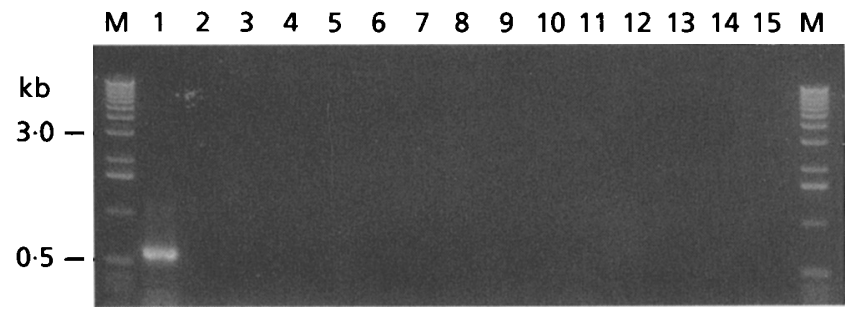

Fig. 5. Agarose gel electrophoresis of the PCR products from different bacterial species using the $f 14$ primers. Lanes: $M, D N A$ molecular mass markers ( $1.0 \mathrm{~kb}$ ladder, Gibco-BRL); $1, \mathrm{CVC}-X y$. fastidiosa; $2-15, E$. coli $\mathrm{DH} 5 \alpha, X a$. axonopodis pv. citri, Xa. axonopodis pv. phaseoli, Xa. campestris pv. campestris, $X a$. translucens pv. translucens, $X a$. translucens pv. undulosa, $P$. cichorii, $P$. syringae pv. garcae, $P$. syringae pv. syringae, $A$. tumefaciens, B. gladioli pv. gladioli, B. andropogonis, En. dissolvens, Er. carotovora subsp. carotovora, respectively.

\section{DISCUSSION}

The use of diagnostic methods to identify the presence of $X y$. fastidiosa in plants is an important step in the implementation of measures to restrict the dissemination of the disease in the field or to a non-infected area. The spread of CVC in the major citrus-growing areas in Brazil, mainly in the São Paulo State, can be considered alarming since approximately $35 \%$ of citrus plants are presently affected (www.fundecitrus.com.br). The use of subtractive hybridization to obtain probes specific for phytopathogenic bacteria has been described and in general the protocols used require construction of a genomic library, various steps of hybridization and labelling. The primers f14 described herein were obtained using a protocol for fast and easy genomic subtraction. The technique, as used previously by
Kunkel et al. (1985), allowed isolation of four human specific fragments among the 81 clones analysed. No specific buffers were required, nor time-consuming purification steps to obtain clean material for cloning. Although various fragments were cloned in the present work, most of them were of too small a size for further detection using amplification in a PCR-based method and therefore they were not analysed. The small size of these fragments indicates that the isolation of fragments between 0.5 and $2.0 \mathrm{~kb}$ was not efficient and more steps of purification of the planned fragment size would improve the differential library cloning. In addition, the transformation procedure in general is more efficient for small inserts (Ferreira et al., 1995), which helps to explain the high frequency of the small inserts obtained. The four clones examined showed no hybridization to the DNA from Xa. campestris pv. campestris and B. gladioli pv. gladioli used as drivers; however, three of the four clones hybridized to the DNA of the third driver strain ( $X y$. fastidiosa PL788). It is possible that using a higher ratio of driver DNA or performing a second round of hybridization would improve the recovery of the differential clones. In fact a ratio of 1:200 was used in the original protocol (Kunkel et al., 1985). The primers $\mathrm{f} 14$ obtained were specific to CVC-Xy. fastidiosa and the low threshold of detection will improve the early diagnosis of symptomless and infected plants.

Specific primers for the detection of $X y$. fastidiosa from citrus, obtained by differential RAPD products, have already been described (Pooler \& Hartung, 1995) and they also amplify $X y$. fastidiosa from coffee (data not shown). Indeed, $X y$. fastidiosa strains isolated from these two hosts are considered closely related (Beretta et al., 1996; Lima et al., 1998; Paradela-Filho et al., 1997), but in our work, the f14 primers showed a differential screening among coffee strains. Three coffee- $X y$. fastidiosa strains isolated in the São Paulo State were not detected by hybridization or PCR experiments. However, two other strains isolated in the Paraná State were detected by PCR. The isolation of other strains from coffee is under way to verify if populations from these major coffee-producing states are distinguishable. The lack of homology of f14 and/or the lack of amplification of $X y$. fastidiosa from grape and plum and different bacterial species indicated that the f14 sequence might be only rarely found within the Gram-negative phytobacteria such as Xanthomonas and Pseudomonas. Common bacterial phytopathogens of citrus (Xa. axonopodis pv. citri) and coffee (B. andropogonis, $P$. cichorii and $P$. syringae pv. garcae) were also tested and showed no amplification product. Amplification using $\mathrm{f} 14$ primers was also obtained to the $X y$. fastidiosa from another host (oleander). The amplification product of $600 \mathrm{bp}$ was similar to that obtained with CVC-Xy. fastidiosa; however, the Southern hybridization experiments showed a smaller hybridizing band in oleander-Xy. fastidiosa, indicating differences in the Sau3AI restriction sites between both fragments. No other strains from oleander were tested, since detection of oleander 
leaf scorch is recent (Purcell \& Hopkins, 1996) and only one strain was available. A faint band of hybridization was detected with DNA from E. coli DH5 $x$, possibly due to various stretches of homology detected between $\mathrm{f} 14$ and the fli $\mathrm{C}$ gene of E. coli.

The sequencing of 14 showed an unexpected similarity in the deduced amino acid sequence to the flagellin of $E$. coli serotypes $\mathrm{H} 1$ and $\mathrm{H} 12$ (Schoenhals \& Whitfield, 1993). Since $X y$. fastidiosa does not have a flagellum (Wells et al., 1987), it is plausible to assign a different function to f14. The flagellin molecule of E. coli presents the antigenic determinant for the $\mathrm{H}$ antigen which is routinely identified by the $\mathrm{H}$ antigen-specific antibodies in the slide agglutination test (Lawn, 1977). Although the similarity between the $\mathrm{F} 14$ and FliC predicted protein sequence appears to be fortuitous, a slide agglutination test was performed using two strains of CVC-Xy. fastidiosa and the results were negative (data not shown).

The simplified subtractive hybridization technique presented here was effective for the isolation of the DNA sequence specific for CVC-Xy. fastidiosa. This sequence was highly specific to the $X y$. fastidiosa isolated from citrus and oleander and appears not to be essential since it is absent in the bacteria isolated from other hosts. The approach used was easy to perform and is potentially applicable for the isolation of specific genes in this littlestudied species and also other micro-organisms.

\section{ACKNOWLEDGEMENTS}

We would like to thank Fundecitrus and IAPAR (R. P. Leite) for providing the strains of $X y$. fastidiosa; to CAPES for the fellowship granted to H. Ferreira, to Dr O. Guerreiro Filho (IAC.) for supplying the coffee plants and to Dr A. Dias for the slide agglutination tests.

\section{REFERENCES}

Beretta, M. J. G., Harakawa, R., Chagas, C. M. \& 7 other authors (1996). First report of Xylella fastidiosa in coffee. Plant Dis $\mathbf{8 0}$, 821.

Carlos, E. F., Rodrigues Neto, J. \& Beretta, M. J. G. (1997). A hactéria Xylella fastidiosa. In Clorose Variegada dos Citros, pp. 22-36. Edited by L. C. Donadio \& C. S. Moreira. Araraquara, Brazil : Fundecitrus.

Chang, C. J., Garnier, M., Zreik, L., Rossetti, V. \& Bové, J. M. (1993). Culture and serological detection of the xylem-limited bacterium causing citrus variegated chlorosis and its identification as a strain of Xylella fastidiosa. Curr Microbiol 27, 137-142.

Cook, D. \& Sequeira, L. (1991). The use of subtractive hybridization to obtain a DNA probe specific for Pseudomonas solanacearum race 3. Mol Gen Gienet 227, 401-410.

Darrasse, A., Kotoujansky, A. \& Bertheau, Y. (1994). Isolation by genomic subtraction of DNA probes specific for Erwinia carotolora subsp. atroseptica. Appl Environ Microbiol 60, 298-306.

Destefano, S. A. L. \& Rosato, Y. B. (1991). Effect of transposon Tn.5 on exopolysaccharide production by Xanthomonas campestris. Rev' Bras Genet 14, 599-607.

Doyle, J. J. \& Doyle, J. L. (1990). Isolation of plant DNA from fresh tissue. Focus 12, 13-1.5.

Ferreira, H., Barrientos, F. J. A., Baldini, R. L. \& Rosato, Y. B.
(1995). Electrotransformation of three pathovars of Xanthomonas campestris. Appl Microbiol Biotechnol 43, 651-655.

Garnier, M., Chang, C. J., Zreik, L., Rosseti, V. \& Bové, J. M. (1993). Citrus variegated chlorosis: serological detection of Xylella fastidiosa, the bacterium associated with the disease. In Conf Int Organ Citrus Virologists 12, 301-305.

Harshey, R. M., Estepa, G. \& Yanagi, Y. (1989). Cloning and nucleotide sequence of a flagellin-coding gene (hag) from Serratia marcescens 274. Gene 79, 1-8.

Hartung, J. S., Beretta, M. J. G., Brlansky, R. H., Spisso, J. \& Lee, R. F. (1994). Citrus variegated chlorosis hacterium, axenic culture, pathogenicity, and serological relationships with other strains of Xylella fastidiosa. Phytopathology 84, 591-597.

Hopkins, D. L. (1989). Xylella fastidiosa, xylem-limited bacterial pathogen of plants. Annu Rev Phytopathol 22, 271-290.

Kohne, D. E., Levison, S. \& Byers, M. J. (1977). Room temperature method for increasing the rate of DNA reassociation by many thousands, the phenol emulsion reassociation technique. Biochemistry 16, 5329-5341.

Kuflu, K. M. \& Cuppels, D. A. (1997). Development of a diagnostic DNA probe for xanthomonads causing bacterial spot of peppers and tomatoes. Appl Environ Microbiol 63, 4462-4470.

Kunkel, L. M., Monaco, A. P., Middlesworth, W., Ochs, H. D. \& Latt, S. A. (1985). Specific cloning of DNA fragments absent from the DNA of a male patient with an $\mathrm{X}$ chromosome deletion. Proc Natl Acad Sci USA 82, 4778-4782.

Lawn, A. M. (1977). Comparison of the flagellins from different flagellar morphotypes of Escherichia coli. J Gen Microbiol 101, 121-130.

Lee, R. F., Beretta, M. J. G., Derrick, K. S. \& Hooker, M. E. (1992). Development of a serological assay for citrus variegated chlorosis, a new disease of citrus in Brazil. Proc Fla State Hortic Sci 102, $32-35$.

Lima, J. E. O., Miranda, V. S., Hartung, J. S., Brlansky, R. H., Coutinho, A. \& Carlos, E. F. (1998). Coffee leaf scorch bacterium: axenic culture, pathogenicity and comparison with Xylella fastidiosa of citrus. Plant Dis 82, 94-97.

Mills, D., Russel, B. W. \& Hanus, J. W. (1997). Specific detection of Clavibacter michiganensis subsp. sepedonicus by amplification of three unique DNA sequences isolated by subtraction hybridization. Phytopathology 87, 853-861.

Minsavage, G. V., Thompson, C. M., Hopkins, D. L., Leite, R. M. V. B. C. \& Stall, R. E. (1994). Development of a polymerase chain reaction protocol for detection of Xylella fastidiosa in plant tissue. Phytopathology 84, 456-461.

Moreno, M. R., Smith, J. F. \& Smith, R. V. (1985). Silver staining of proteins in polyacrylamide gels, increased sensitivity through a combined Coomassie blue-silver stain procedure. Anal Biochem 151, 466-470.

Paradela-Filho, O., Sugimori, M. H., Ribeiro, I. J. A. \& 7 other authors (1997). Occurrence of Xylella fastidiosa in coffee plants in Brazil. Summa Phytopathol 23, 46-49.

Pooler, M. R. \& Hartung, J. S. (1995). Specific detection and identification of Xylella fastidiosa strains causing citrus variegated chlorosis. Curr Microbiol 31, 377-381.

Purcell, A. H. \& Hopkins, D. L. (1996). Fastidious xylem-limited bacterial plant pathogen. Annu Rev Phytopathol 34, 131-151.

Sambrook, J., Fritsch, E. F. \& Maniatis, T. (1989). Molecular Cloning: a Laboratory Manual, 2nd edn. Cold Spring Harbor, NY : Cold Spring Harbor Laboratory.

Schoenhals, G. \& Whitfield, C. (1993). Comparative analysis of 
flagellin sequences from Escherichia coli strains possessing serologically distinct flagellar filaments with a shared complex surface pattern. J Bacteriol 175, 5395-5402.

Smith, N. H. \& Selander, R. K. (1990). Sequence invariance of the antigen-coding central region of the phase 1 flagellar filament gene $(\mathrm{fli})$ among strains of Salmonella typhimurium. J Bacteriol 172, 603-609.

Straus, D. \& Ausubel, F. M. (1990). Genomic subtraction for cloning DNA corresponding to deletion mutation. Proc Natl Acad Sci USA 87, 1889-1893.

Turner, T., Barber, C. \& Daniels, M. J. (1984). Behaviour of the transposons $\operatorname{Tn} 5$ and $\operatorname{Tn} 7$ in Xanthomonas campestris pv. campestris. Mol Gen Genet 195, 101-107.

Wei, L.-N. \& Joys, T. M. (1986). The nucleotide sequence of the H-1 gene of Salmonella rubislaw. Nucleic Acids Res 14, 8227.

Wells, J. M., Raju, B. C., Hung, H. Y., Weisburg, W. G., MandelcoPaul, L. \& Brenner, D. J. (1987). Xylella fastidiosa gen. nov., sp. nov.: Gram-negative, xylem-limited, fastidious plant bacteria related to Xanthomonas spp. Int J Syst Bacteriol 37, 136-143.

Received 8 February 1999; revised 31 March 1999; accepted 12 April 1999. 